\title{
Dye-Sensitized Solar Cells and Solar Module Using Polymer Electrolytes: Stability and Performance Investigations
}

\author{
Jilian Nei de Freitas, Viviane Carvalho Nogueira, Bruno leiri Ito, Mauro Alfredo Soto-Oviedo, \\ Claudia Longo, Marco-Aurelio De Paoli, and Ana Flávia Nogueira
}

\begin{abstract}
Laboratório de Nanotecnologia e Energia Solar (LNES), Instituto de Química, UNICAMP, C. Postal 6154, Campinas, SP 13084-971, Brazil
\end{abstract}

Received 16 February 2006; Revised 21 June 2006; Accepted 21 June 2006

\begin{abstract}
We present recent results on solid-state dye-sensitized solar cell research using a polymer electrolyte based on a poly(ethylene oxide) derivative. The stability and performance of the devices have been improved by a modification in the method of assembly of the cells and by the addition of plasticizers in the electrolyte. After 30 days of solar irradiation $\left(100 \mathrm{~mW} \mathrm{~cm}^{-2}\right)$ no changes in the cell's efficiency were observed using this new method. The effect of the active area size on cell performance and the first results obtained for the first solar module composed of $4.5 \mathrm{~cm}^{2}$ solid-state solar cells are also presented.
\end{abstract}

Copyright (c) 2006 Jilian Nei de Freitas et al. This is an open access article distributed under the Creative Commons Attribution License, which permits unrestricted use, distribution, and reproduction in any medium, provided the original work is properly cited.

\section{INTRODUCTION}

Since Grätzel's announcement of the first dye-sensitized nanocrystalline solar cell (DSSC) as a promising, low cost, clean and highly efficient device for solar energy conversion, many groups have focused their efforts on improving and comprehending this technology in its different aspects. The liquid electrolyte usually employed in this cell is still a drawback for long-term practical operation and causes substantial problems to bring DSSC onto the market. To overcome these problems, many research groups have been searching for alternatives to replace the liquid electrolytes, such as inorganic or organic hole conductors $[1,2]$, ionic liquids $[3,4]$ and polymers $[5,6]$, and gel electrolytes $[7,8]$.

Since 1996, our group has been working on DSSC using polymer electrolytes based on the copolymer poly(epichlorohydrin-co-ethylene oxide), $\mathrm{P}(\mathrm{EPI}-\mathrm{EO})$, and the first results were published in 1999 [9]. The best solar energy conversion efficiency device obtained for a solid-state DSSC $\left(1 \mathrm{~cm}^{2}\right.$ of active area) was $2.6 \%$ under $10 \mathrm{~mW} \mathrm{~cm}^{-2}$ and $1.6 \%$ under $100 \mathrm{~mW} \mathrm{~cm}^{-2}$ [10]. However, our results indicate that the overall efficiency has already reached the limit for a system based solely on polymers and salt/iodine mixtures. Other components must be added to this system in order to develop cells with enhanced efficiency, since the cell's performance is directly related to the polymer electrolyte ionic conductivity, which is a consequence of the $\mathrm{I}_{3}{ }^{-} / \mathrm{I}^{-}$mobility inside the polymer matrix.

In this report we summarize our recent experimental efforts to improve the ionic conductivity of the polymer electrolyte, looking towards solar cells with improved performance. We investigated the addition of $\gamma$-butyrolactone as plasticizer to electrolytes based on $\mathrm{P}(\mathrm{EO}-\mathrm{EPI})$ copolymers. The optimization of polymer electrolyte composition and cell assembly leads to devices with better efficiency and enhanced stability. We also discuss the performance of solar cells with large active areas and present the first results of a solar module assembled with DSSC using a polymer electrolyte.

\section{EXPERIMENTAL}

\subsection{Materials}

Samples of poly(ethylene oxide-co-epichlorohydrin) were used as received from Daiso Co. Ltd. (Osaka). The ethylene oxide/epichorohydrin ratio in the copolymers were 50/50, $84 / 16$, and $87 / 13$, and they are designated as P(EO-EPI) 50 : 50, $\mathrm{P}(\mathrm{EO}-\mathrm{EPI}) 84$ : 16, and $\mathrm{P}(\mathrm{EO}-\mathrm{EPI}) 87: 13$, respectively. The molar masses of the copolymers reported by the supplier were circa $1 \times 10^{6} \mathrm{~g} \mathrm{~mol}^{-1}$. The polymer electrolytes were prepared by the dissolution of the copolymer, $\mathrm{NaI}, \mathrm{I}_{2}$, and the plasticizer in acetone. The plasticizer investigated 
was $\gamma$-butyrolactone, GBL, (Aldrich, 99\%). In all cases, the copolymer/plasticizer weight ratio was $1: 1$.

\subsection{Thermogravimetric analysis (TGA)}

Thermogravimetric curves were obtained for the pure copolymer P(EO-EPI)84 : 16 and two polymer electrolyte samples containing $\mathrm{P}(\mathrm{EO}-\mathrm{EPI}) 84: 16+11 \mathrm{wt} \%$ of $\mathrm{NaI} / \mathrm{I}_{2}$. The polymer electrolyte samples were prepared by casting the polymer electrolyte solution under a saturated solvent atmosphere, reproducing the conditions usually employed in DSSC assembly. The samples were prepared on the same day; however thermogravimetric analysis (TGA) were carried out on different days for the two samples in order to understand the role of the solvent. The TGA for the first sample was carried out immediately after sample preparation (1st day). For the other sample, the TGA was carried out on the 5th day. TGA curves were measured using a thermogravimetric analyzer model 2950 from TA Instruments. All measurements were done under continuous argon flow $\left(100 \mathrm{~mL} \mathrm{~min}^{-1}\right)$, heating from room temperature to $600^{\circ} \mathrm{C}$ at $10^{\circ} \mathrm{C} \mathrm{min}^{-1}$.

\subsection{Ionic conductivity measurements}

Ionic conductivity measurements were evaluated as a function of salt concentration for polymer electrolytes prepared with and without plasticizers. All samples consisted of polymer electrolyte films (thickness of circa $100 \mu \mathrm{m}$ ), obtained by casting electrolyte solutions onto a Teflon disk, under saturated atmosphere conditions. Afterwards, the films were detached from the Teflon by dipping into liquid nitrogen, and further dried under vacuum for 144 hours. Conductivity measurements were carried out in a MBraun dry box (humidity $<10^{-4} \%$, under an argon atmosphere). The films were fixed between two mirror-polished stainless steel disc shaped electrodes (diameter $=12 \mathrm{~mm}$ ) and the conductivity values were calculated from the data obtained by electrochemical impedance spectroscopy (EIS), using an EcoChemie Autolab PGSTAT 12 with FRA module coupled to a computer in the frequency of $10^{6}$ to $10 \mathrm{~Hz}$ and amplitude of $10 \mathrm{mV}$ applied to $0 \mathrm{~V}$.

\subsection{Dye-sensitized $\mathrm{TiO}_{2}$ solar cell assembly}

DSSC were assembled using glass-FTO (Hartford glass, Rs $\leq 10 \Omega \mathrm{cm}^{-2}$ ) and glass-ITO (Delta Technologies, Rs $\leq 30 \Omega \mathrm{cm}^{-2}$ ) electrodes as substrates for the photo and counter-electrodes, respectively. Counter-electrodes (CE) were prepared by Pt sputtering ( $400 \AA)$ onto the glassITO electrodes. For preparation of photoelectrodes, a small aliquot of $\mathrm{TiO}_{2}$ suspension was spread using a glass rod onto glass-FTO electrodes with an adhesive tape as spacer. The $\mathrm{TiO}_{2}$ electrodes (thickness $\sim 6 \mu \mathrm{m}$ ) were heated at $450^{\circ} \mathrm{C}$ for 30 minutes, cooled to $\sim 80^{\circ} \mathrm{C}$, and then immersed in a $1.5 \times 10^{-4} \mathrm{~mol} \mathrm{~L}^{-1}$ solution of the sensitizer dye cis-bis(isothiocyanato)bis(2,2' -bipyridyl4,4'-dicarboxylic acid)-ruthenium(II), Ruthenium-535, Solaronix) in absolute ethanol for 16 hours. Afterwards, the electrodes were rinsed with ethanol and dried. A film of the polymer electrolyte was cast onto the sensitized electrodes under a saturated solvent atmosphere. An alternative procedure for polymer electrolyte deposition consisted in casting the solution onto the electrodes placed on a hot plate at $60^{\circ} \mathrm{C}$. The final assembly of the DSSC was done by pressing the $\mathrm{CE}$ against the sensitized electrode coated with the polymer electrolyte. An adhesive tape was placed between the two electrodes, in order to control electrolyte film thickness and to avoid short-circuiting of the cell. All devices were placed in a desiccator with $\mathrm{P}_{2} \mathrm{O}_{5}$ for 2 hours to remove moisture.

The DSSC devices were characterized on an optical bench using an Oriel Xe (Hg) $250 \mathrm{~W}$ lamp, lenses, water, and cutoff filters to avoid IR and UV radiation, respectively. The light intensity was measured with a Newport Optical Power Meter. Current-potential curves ( $\mathrm{J}-\mathrm{V}$ curves) were obtained using linear sweep voltammetry at $1 \mathrm{mV} \mathrm{s}^{-1}$ using an Eco-ChimieAutolab PGSTAT 12 potentiostat. The stability tests were performed daily, irradiating each cell for 1 hour at $100 \mathrm{~mW} \mathrm{~cm}^{-2}$ in short-circuit conditions, for approximately 35 days.

A solar module was built by connecting in series 13 cells with $4.5 \mathrm{~cm}^{2}$ of active area. These cells were assembled using a glass-FTO from Saint-Gobain (EKO-EM1, 10-14 $\Omega$ ) and the counter electrodes were prepared by thermal decomposition of a $5 \times 10^{-3} \mathrm{~mol} \mathrm{~L}^{-1}$ solution of $\mathrm{H}_{2} \mathrm{PtCl}_{6} \cdot n \mathrm{H}_{2} \mathrm{O}$ (Acros Organics) in 2-propanol. The electric contacts between adjacent cells were done by placing copper wires on the FTOglasses and further covering them with colloidal conductive carbon glue. The solar module was placed on the rooftop of the Chemistry Building at the Universidade Estadual de Campinas (lat $5522^{\circ} 49.08^{\prime}$; long W47 $04.11^{\prime}$ ) for outdoor performance tests. Electric parameters were monitored during the day. No corrections were made for the $30 \%$ reflection and transmission losses of the FTO-glasses.

\section{RESULTS AND DISCUSSION}

\subsection{Solar cell stability}

Figure 1 shows the variation of energy conversion efficiency $(\eta)$ as a function of time for a device assembled with polymer electrolyte deposited by casting under a saturated solvent atmosphere and for a device assembled with polymer electrolyte deposited by alternative casting at $60^{\circ} \mathrm{C}$. All the measurements were carried out at a light intensity of $100 \mathrm{~mW} \mathrm{~cm}^{-2}$. The data revealed that for the cell assembled with the polymer electrolyte deposited by casting under a saturated solvent atmosphere, there was a decay of $72 \%$ in the cell's efficiency ( $\eta$ from 1.0 to $0.3 \%$ ) during the first 30 days. For the cell assembled with the alternative procedure, $\eta$ remained constant over the same period. After the 30th day, both cells exhibit similar performance, indicating that the apparent better initial performance of the "moisturized cell" might be a consequence of residual solvent present in the electrolyte. This residual solvent, in this case, acetone, increases the ionic conductivity of the electrolyte (or the mobility of charge carriers), giving rise to higher values of photocurrent. As the solvent evaporates, the ionic conductivity 


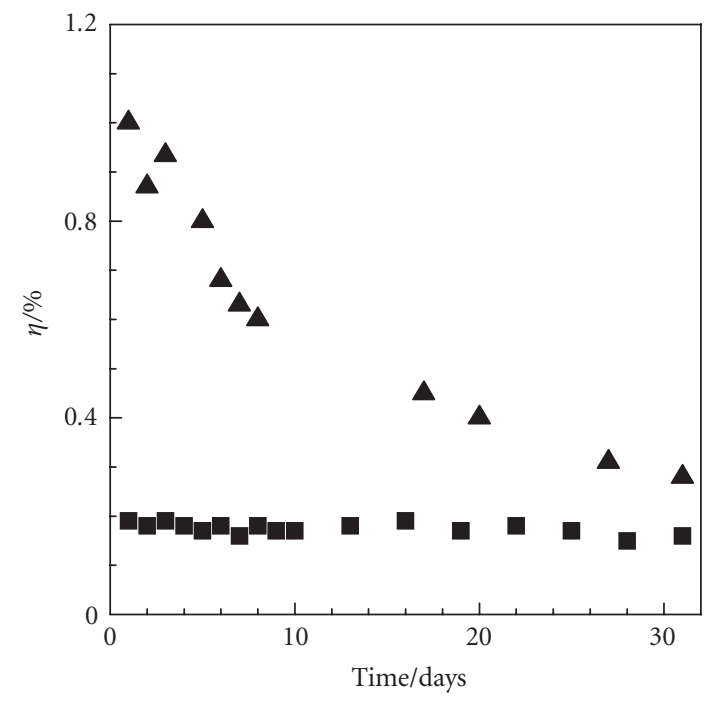

FIgURE 1: The variation of energy conversion efficiency under $100 \mathrm{~mW} \mathrm{~cm}^{-2}$ as a function of time for a solid-state DSSC assembled with a $\mathrm{P}(\mathrm{EPI}-\mathrm{EO})+11 \mathrm{wt} \% \mathrm{NaI} / \mathrm{I}_{2}$ polymer electrolyte deposited by casting under a saturated solvent atmosphere $(\boldsymbol{\Lambda})$ and deposited by casting at $60^{\circ} \mathrm{C}(\boldsymbol{\square})$.

decreases followed by a decrease in the cell's efficiency. A similar behavior was observed in an earlier work involving a DSSC assembled with flexible and rigid substrates (ITOPET and ITO-glass) [11]. The loss of solvent in the "moisturized cell" also results in the formation of empty holes (spaces) which contribute to increasing the overall cell resistance and affect the contact between the electrodes, lowering the fill factor. In order to fully characterize the role of the residual solvent on the cell's efficiency, thermogravimetric analyses were carried out on two polymer electrolyte samples prepared by casting the polymer electrolyte under a saturated solvent atmosphere, reproducing the conditions usually employed during DSSC assembly. Both samples were prepared at the same time; however TGA were carried out in different days. TGA for the first sample was carried out immediately after sample preparation (1st day). For the other sample, TGA was carried out on the 5th day. The TGA curve (Figure 2) for the pristine $\mathrm{P}(\mathrm{EPI}-\mathrm{EO}) 84: 16$ sample showed only one mass loss step at $336^{\circ} \mathrm{C}$ (maximum mass loss temperature, $\mathrm{T}_{\mathrm{dec}}$ ) associated to the thermal degradation of the copolymer, due to the loss of chlorine radicals and $\mathrm{HCl}$ release, in analogy to the thermal degradation of poly(vinyl chloride) [12]. Both polymer electrolyte samples presented two significant mass loss steps in the temperature region below $400^{\circ} \mathrm{C}$. The first step $\left(\mathrm{T}<200^{\circ} \mathrm{C}\right)$ is associated to the loss of residual solvent and water and the second is associated to the thermal degradation of the copolymer. For the sample analyzed immediately after preparation, $50 \%$ of mass loss is attributed to residual solvent and water. For the sample kept in ambient conditions for 5 days and then analyzed, the solvent/water loss was reduced to $10 \%$. These results indicate that the casting procedure usually employed for gel and polymer electrolytes leaves a high amount of residual solvent

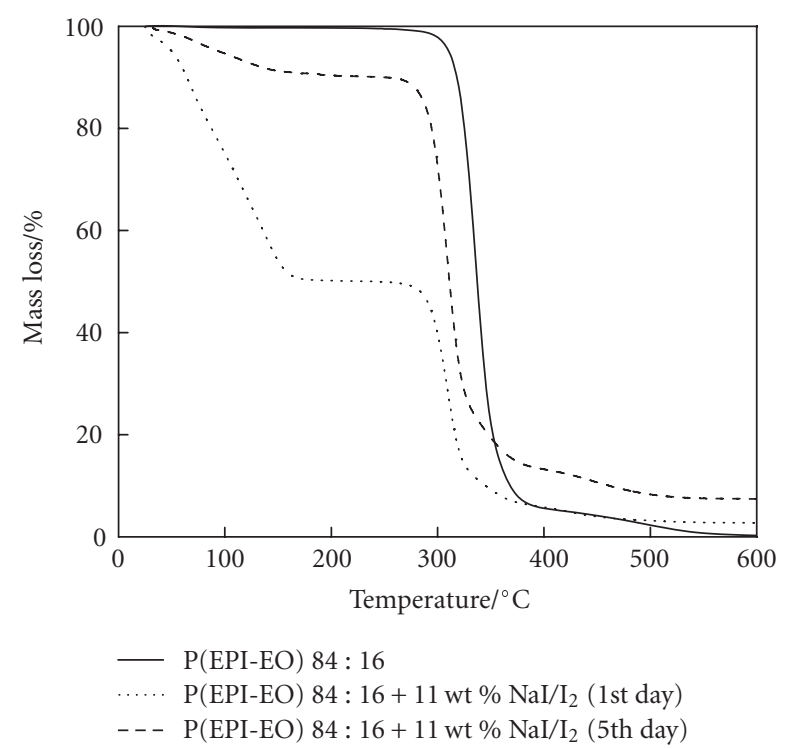

Figure 2: Thermogravimetric curves for P(EPI-EO)84: 16 and $\mathrm{P}(\mathrm{EPI}-\mathrm{EO}) 84: 16+11 \mathrm{wt} \% \mathrm{NaI} / \mathrm{I}_{2}$ samples prepared by casting the polymer electrolyte under a saturated solvent atmosphere.

and water in the device that is released gradually during postassembly.

The removal of solvent and water prior to device closing, however, reduces the polymer ionic conductivity, since these small molecules also serve as a second path for charge carrier motions.

It was also observed that, even after the removal of the residual acetone by heating the sample at $60{ }^{\circ} \mathrm{C}$, the performance of the devices presented a decay with time when operating under outdoor conditions [13]. Investigations on the stability of the polymer electrolyte have indicated that the polymer is stable at the temperature conditions in which solar cells normally operate [14]. Therefore, the devices might be degrading in a similar way to that observed for liquid solar cells. Several studies have reported that the origin of cell degradation might be related to dye desorption or degradation, accelerated by temperature [15]. Another factor that might have a strong influence on cell stability is the low mobility or concentration of iodide species inside the $\mathrm{TiO}_{2}$ film, which increases the average time in which the dye remains in the oxidized state [16]. Is important to emphasize that for future application of DSSC modules, a good sealing is necessary. This requirement is important in order to minimize all the factors described above, which affect drastically the long term stability of the devices.

\subsection{Polymer electrolyte with enhanced ionic conductivity}

Although stability is an important issue in the development of solar cells and modules capable of being commercialized, the market also demands cells with performance similar to that exhibited by silicon technology. 


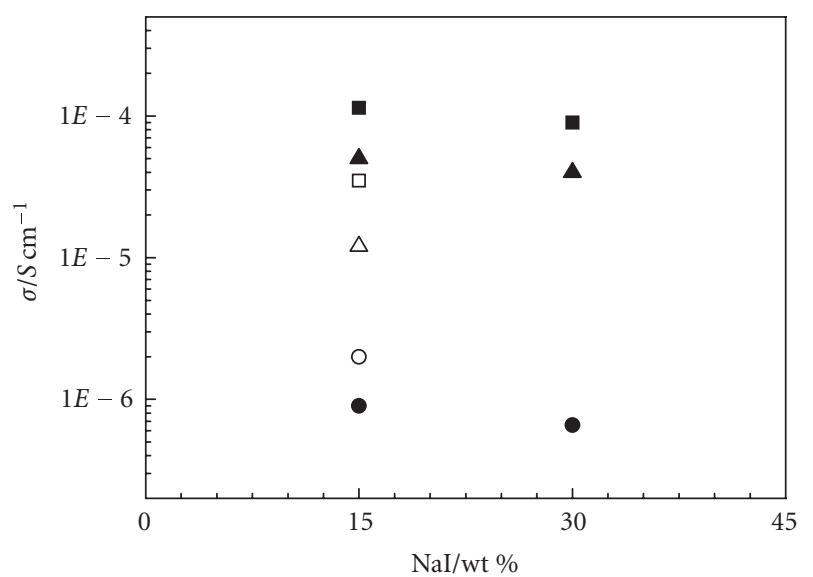

FIgURE 3: Ionic conductivity as a function of NaI concentration for different polymer electrolytes with (solid) and without (open) GBL: $(\circ, \bullet) \mathrm{P}($ EO-EPI) $50: 50,(\Delta, \mathbf{\Delta}) \mathrm{P}($ EO-EPI $) 84: 16$, and $(\square, \boldsymbol{\square})$ $\mathrm{P}(\mathrm{EO}-\mathrm{EPI}) 87: 13$.

According to these observations, the processing of devices with better stability and higher performance was pursued. Thus, polymer electrolytes were prepared with the addition of $\gamma$-butyrolactone, GBL, as a plasticizer. GBL is a low molar mass organic liquid, with low vapor pressure, low viscosity and stable in the temperature range of operating cells.

Figure 3 exhibits the ionic conductivity as a function of $\mathrm{NaI}$ concentration for different polymer electrolytes with and without $\gamma$-butyrolactone. The amount of salt that was added considered solely the polymer content.

For polymer electrolytes prepared without the plasticizer, the higher ionic conductivity was achieved for the copolymer with higher content of EO units, $\mathrm{P}(\mathrm{EO}-\mathrm{EPI}) 87: 13$. This behavior is in agreement with previous reports on $\mathrm{P}(\mathrm{EO}-$ EPI) copolymers, where only the EO units interact effectively with the ions, and thus contribute effectively for ionic conductivity. The low interaction of the epichlorohydrin unit is due to the electronegativity of the chlorine atom which withdraws electron density from the oxygen [17]. Therefore, one could expect that a large amount of EO units would give origin to a higher ionic conductivity. However, it also leads to an increase in the crystallinity degree of the copolymer (the copolymer P(EO-EPI) $50: 50$ is fully amorphous while pure poly(ethylene oxide) has $80 \%$ crystallinity). The increase in crystallinity degree reduces the ionic conductivity of polymer electrolytes, since ionic transport is expected to occur predominantly in the amorphous phase of the polymer matrix. On the other hand, the high content of EO units in the copolymers P(EO-EPI)87 : 13 and P(EO-EPI) $84: 16$ allows a larger amount of salt to be dissolved, due to more oxygen sites available to coordinate the $\mathrm{Na}^{+}$ions. The results presented in Figure 3 show that this effect is the predominant one, because even with the high degree of crystallinity exhibited by the copolymer with higher EO content, this polymer showed the highest values of ionic conductivity.

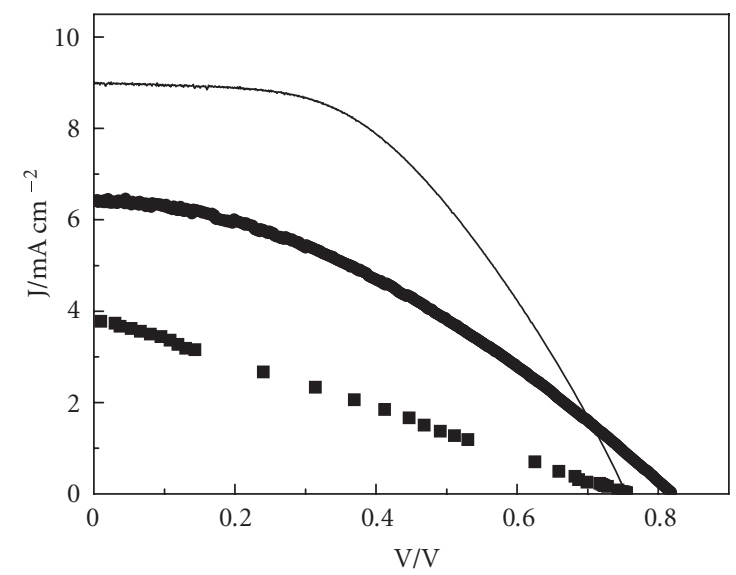

FIgURE 4: J-V curves obtained under $100 \mathrm{~mW} \mathrm{~cm}^{-2}$ polychromatic irradiation for dye-sensitized solar cells assembled with polymer electrolyte (P(EO-EPI) $\left.87: 13+15 \mathrm{wt} \% \mathrm{NaI} / \mathrm{I}_{2}+\mathrm{GBL}\right)$, with different active areas: (-) $0.25 \mathrm{~cm}^{2},(-) 1 \mathrm{~cm}^{2}$, and $(\mathbf{\square}) 4.5 \mathrm{~cm}^{2}$.

The same trend in ionic conductivity was observed when analyzing the polymer electrolytes containing GBL as plasticizer. Again, the higher ionic conductivity values are obtained for the copolymer P(EO-EPI) $87: 13$ after the addition of plasticizer. This result is in agreement with the high content of ethylene oxide in this copolymer, indicating that the plasticizer is acting directly between the polymer chains disrupting the crystalline phase.

Besides, for the plasticized polymer electrolytes the ionic conductivity remains almost constant even after addition of a large amount of salt (30 wt \%). This effect is not observed when no plasticizer is added. In this case, the maximum in the ionic conductivity curve is reached between 10 and $15 \%$ of salt. After this point, an abrupt decrease in the ionic conductivity is observed when the amount of salt is increased [18]. Thus, the addition of plasticizer has important effects on cell performance by increasing the ionic conductivity of the electrolyte since it promotes salt dissociation and transport of charges, and also favors the cell stability since it allows a higher amount of salt to be added. Thus, as a consequence more dye cations are regenerated. The ability of GBL to coordinate ions and contribute to ionic conductivity has already been shown for gel electrolytes based on PEO and lithium salts [19]. The ability to dissociate more salt was also demonstrated in an earlier work using poly(ethylene glycol methyl ether) (PEGME) as plasticizer [14]. In the same work the addition of PEGME does produce devices with enhanced photo-current and efficiency responses, which are probably a consequence of the enhancement in ionic conductivity of the electrolyte [14].

\subsection{Solar cell performance}

Figure 4 shows the J-V curves obtained for several dyesensitized solar cells with different active areas, all assembled with $\mathrm{P}(\mathrm{EO}-\mathrm{EPI}) 87: 13+15 \mathrm{wt} \%$ of $\mathrm{NaI} / \mathrm{I}_{2}+\mathrm{GBL}$. The 
parameters calculated from these curves were summarized in Table 1.

As expected, the results show that higher photocurrent values are obtained for devices with large active areas (see Table 1). However, the increase in the current is not proportional to area enlargement, as can be seen when the curves are evaluated considering the current density (Jsc), defined as photocurrent per square centimeter (Figure 4). One could expect similar values of Jsc if the materials did not present a great increase in overall resistance with area enlargement. Figure 4 shows that the diode profile of the J-V curves is replaced by an ohmic profile when the area of the device is increased. The series resistance estimated from the J-V curves corresponds to circa 40,85, and $200 \Omega$ for cells with active areas of $0.25,1.0$, and $4.5 \mathrm{~cm}^{2}$, respectively. This increase in the internal resistance is a drawback when scaling up these devices. The same effect is also observed for liquid solar cells and has its origin in the increase of the resistance of the FTO layer, which limits current collection in back contact, that is, there is a loss in the maximum current that can flow through the device. Table 1 shows that the smaller the active area, the higher Jsc, efficiency $(\eta)$, and fill factor (FF). These results indicate that for small areas the substrate is not a limiting factor as it is for large area devices. We observed that increasing the active area by a factor of $\sim 4$ leads to a decrease in efficiency of approximately half. The fill factor is also reduced by $20-30 \%$ when the area is enlarged, because of the poor electrical contact in the cell, which reflects the interface with the FTO-glass.

Such limitations in device performance were previously reported by Okada et al. [20]. These authors showed that the lack of grid collectors in the substrates significantly reduces the performance of dye-sensitized solar cells assembled with liquid electrolytes. Therefore, although the ionic conductivity of the polymer electrolyte investigated here is still one order of magnitude lower than the liquid electrolyte, the internal resistance in the solid electrolyte is not as crucial in determining the FF and $\eta$ values as the FTO layer resistance. However, the electric resistivity of the FTO-glass is not the only factor determining the overall efficiency. When the active area was increased, the $\mathrm{TiO}_{2}$ film deposited by the doctor blade technique became less homogeneous, with poor adhesion to the FTO layer. This effect can be minimized by modifying the properties of the $\mathrm{TiO}_{2}$ colloidal suspension, or by employing techniques of deposition more suitable for large-scale production, such as spin-coating or screenprinting.

\subsection{Solar module performance}

After the characterization of individual cells, 13 DSSC with $4.5 \mathrm{~cm}^{2}$ of active area were connected in series to build a solar module made with a polymer electrolyte. Figure 5 shows the plots of maximum power (Pmax) and open circuit potential (Voc) generated by the module during one day of irradiation (January/2005), from 6 am to 7 pm, in Campinas, Brazil. The total short circuit current of the module corresponds to the average of the current generated by each cell and the open
TABle 1: Photocurrent (Isc), density of current (Jsc), voltage (Voc), fill factor $(\mathrm{FF})$, and efficiency $(\eta)$ presented by dye-sensitized solar cells assembled with polymer electrolyte (P(EO-EPI)87 : $13+$ $\left.15 \mathrm{wt} \% \mathrm{NaI} / \mathrm{I}_{2}+\mathrm{GBL}\right)$ with different active areas (AA), under $100 \mathrm{~mW} \mathrm{~cm}^{-2}$.

\begin{tabular}{l|ccccc}
\hline $\mathrm{AA} / \mathrm{cm}^{2}$ & $\mathrm{Isc} / \mathrm{mA}$ & $\mathrm{Jsc} / \mathrm{mA} \mathrm{cm}{ }^{2}$ & $\mathrm{Voc} / \mathrm{V}$ & $\mathrm{FF} / \%$ & $\eta / \%$ \\
\hline 0.25 & 2.3 & 9 & 0.76 & 47 & 3 \\
1 & 6.4 & 6.4 & 0.81 & 37 & 1.8 \\
4.5 & 17.0 & 3.8 & 0.76 & 26 & 0.8 \\
\hline
\end{tabular}

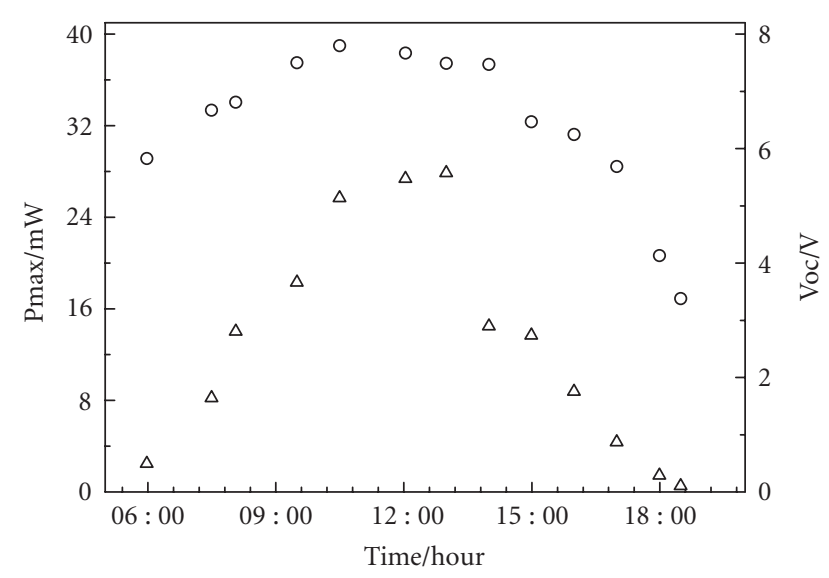

FIgURe 5: Variation of the maximum power $(\operatorname{Pmax}=\Delta)$ and open circuit potential $(\mathrm{Voc}=\circ$ ) produced by the solar module assembled with 13 series-connected solar cells during one day of outdoor exposure.

circuit potential corresponds to the sum of the potential generated by each cell. The module composed of 13 solar cells connected in series presented overall Voc of $\sim 8 \mathrm{~V}$ under irradiation from 10 am to $2 \mathrm{pm}$. The maximum power generated was $28 \mathrm{~mW}$, at $1 \mathrm{pm}$, and the integrated power generated during the whole period of irradiation was $183 \mathrm{~mW}$. The profile of the open circuit voltage and maximum power resembles the variation of solar irradiation during the day. Complete characterization of this solar module will be published elsewhere [13].

To our knowledge, the present module was the first prototype ever built with a polymer electrolyte. Although its performance is low in comparison to other solar modules assembled with liquid electrolytes, some points must be considered. For instance, the module had an active area $\left(58.5 \mathrm{~cm}^{2}\right)$ which is small compared to other modules reported in the literature and, therefore, lower values of power generation are expected. Also, the lack of grid collectors lowered the expected current values, because of the low conductivity of the substrate, as discussed above. Nevertheless, the results obtained are considered very promising and further improvements in module assembly are under investigation. Solar cells with $4.5 \mathrm{~cm}^{2}$ of active area were prepared with substrates containing a metallic grid, and we observed that this modification, indeed, improved the performance of the devices. 


\section{CONCLUSIONS}

For DSSC, stability and performance are two critical issues that must be considered when scaling up these devices. In this work we showed that the stability of dye-sensitized solar cells assembled with polymer electrolytes can be improved by the removal of residual solvent. Also, the performance of these devices can be further improved by the addition of a plasticizer in the polymer electrolyte, which acts directly between the polymer chains, disrupting the crystalline phase and enhancing the ionic conductivity. The performance of dye-sensitized solar cells assembled with the plasticized polymer electrolyte was evaluated as a function of active area size. With area enlargement, the performance of the cell decreases, as a consequence of the loss of current flowing through the device, mainly caused by an increase in the internal resistance of the device. Although the performance obtained for solar cells assembled with $4.5 \mathrm{~cm}^{2}$ of active area was low, 13 cells were connected in series to compose the first solar module built with solid-state dye-sensitized solar cells. The module showed a very promising performance, and generated $8 \mathrm{~V}$ under outdoor conditions.

\section{ACKNOWLEDGMENTS}

The authors acknowledge financial support from FAPESP (fellowships 03/04956-0 and 03/05204-1, project 04/060316) and Daiso Co. Ltd., Osaka, Japan, for providing the copolymers samples.

\section{REFERENCES}

[1] Y. Saito, N. Fukuri, R. Senadeera, T. Kitamura, Y. Wada, and S. Yanagida, "Solid state dye sensitized solar cells using in situ polymerized PEDOTs as hole conductor," Electrochemistry Communications, vol. 6, no. 1, pp. 71-74, 2004.

[2] Q.-B. Meng, K. Takahashi, X.-T. Zhang, et al., "Fabrication of an efficient solid-state dye-sensitized solar cell," Langmuir, vol. 19, no. 9, pp. 3572-3574, 2003.

[3] K. Suzuki, M. Yamaguchi, S. Hotta, N. Tanabe, and S. Yanagida, "A new alkyl-imidazole polymer prepared as an inonic polymer electrolyte by in situ polymerization of dye sensitized solar cells," Journal of Photochemistry and Photobiology A: Chemistry, vol. 164, no. 1-3, pp. 81-85, 2004.

[4] R. Kawano, H. Matsui, C. Matsuyama, et al., "High performance dye-sensitized solar cells using ionic liquids as their electrolytes," Journal of Photochemistry and Photobiology A: Chemistry, vol. 164, no. 1-3, pp. 87-92, 2004.

[5] A. F. Nogueira, C. Longo, and M.-A. De Paoli, "Polymers in dye sensitized solar cells: overview and perspectives," Coordination Chemistry Reviews, vol. 248, no. 13-14, pp. 1455-1468, 2004.

[6] S. A. Haque, E. Palomares, H. M. Upadhyaya, et al., "Flexible dye sensitised nanocrystalline semiconductor solar cells," Chemical Communications, vol. 9, no. 24, pp. 3008-3009, 2003.

[7] P. Wang, S. M. Zakeeruddin, J. E. Moser, M. K. Nazeeruddin, T. Sekiguchi, and M. Grätzel, "A stable quasi-solid-state dyesensitized solar cell with an amphiphilic ruthenium sensitizer and polymer gel electrolyte," Nature Materials, vol. 2, no. 6, pp. 402-407, 2003.
[8] N. Mohmeyer, P. Wang, H.-W. Schmidt, S. M. Zakeeruddin, and M. Grätzel, "Quasi-solid-state dye sensitized solar cells with 1,3:2,4-di-O-benzylidene-D-sorbitol derivatives as low molecular weight organic gelators," Journal of Materials Chemistry, vol. 14, no. 12, pp. 1905-1909, 2004.

[9] A. F. Nogueira, N. Alonso-Vante, and M.-A. De Paoli, "Solidstate photoelectrochemical device using poly (o-methoxy aniline) as sensitizer and an ionic conductive elastomer as electrolyte," Synthetic Metals, vol. 105, no. 1, pp. 23-27, 1999.

[10] A. F. Nogueira, J. R. Durrant, and M.-A. De Paoli, "Dyesensitized nanocrystalline solar cells employing a polymer electrolyte," Advanced Materials, vol. 13, no. 11, pp. 826-830, 2001.

[11] C. Longo, J. N. de Freitas, and M.-A. De Paoli, "Performance and stability of $\mathrm{TiO}_{2}$ /dye solar cells assembled with flexible electrodes and a polymer electrolyte," Journal of Photochemistry and Photobiology A: Chemistry, vol. 159, no. 1, pp. 33-39, 2003.

[12] G. G. Silva, N. H. T. Lemes, C. N. Polo da Fonseca, and M.-A. De Paoli, "Solid state polymeric electrolytes based on poly(epichlorohydrin)," Solid State Ionics, vol. 93, no. 1-2, pp. 105-116, 1996.

[13] J. N. de Freitas, C. Longo, A. F. Nogueira, and M.-A. De Paoli, submitted for publication.

[14] V. C. Nogueira, C. Longo, A. F. Nogueira, M. A. Soto-Oviedo, and M.-A. De Paoli, "Solid-state dye-sensitized solar cell: improved performance and stability using a plasticized polymer electrolyte," Journal of Photochemistry and Photobiology A: Chemistry, vol. 181, no. 2-3, pp. 226-232, 2006.

[15] P. M. Sommeling, M. Späth, H. J. P. Smit, N. J. Bakker, and J. M. Kroon, "Long-term stability testing of dye-sensitized solar cells," Journal of Photochemistry and Photobiology A: Chemistry, vol. 164, no. 1-3, pp. 137-144, 2004.

[16] M. Junghänel and $H$. Tributsch, "Role of nanochemical environments in porous $\mathrm{TiO}_{3}$ in photocurrent efficiency and degradation in dye sensitized solar cells," Journal of Physical Chemistry B, vol. 109, no. 48, pp. 22876-22883, 2005.

[17] W. A. Gazotti, M. A. S. Spinacé, E. M. Girotto, and M.A. De Paoli, "Polymer electrolytes based on ethylene oxideepichlorohydrin copolymers," Solid State Ionics, vol. 130, no. 3-4, pp. 281-291, 2000.

[18] A. F. Nogueira, M. A. S. Spinacé, W. A. Gazotti, E. M. Girotto, and M.-A. De Paoli, "Poly(ethylene oxide-coepichlorohydrin)/NaI: a promising polymer electrolyte for photoelectrochemical cells," Solid State Ionics, vol. 140, no. 34, pp. 327-335, 2001.

[19] K. Hayamizu, Y. Aihara, S. Arai, and W. S. Price, "Selfdiffusion coefficients of lithium, anion, polymer, and solvent in polymer gel electrolytes measured using ${ }^{7} \mathrm{Li},{ }^{19} \mathrm{~F}$, and ${ }^{1} \mathrm{H}$ pulsed-gradient spin-echo NMR," Electrochimica Acta, vol. 45, no. 8-9, pp. 1313-1319, 2000.

[20] K. Okada, H. Matsui, T. Kawashima, T. Ezure, and N. Tanabe, "100 mm × $100 \mathrm{~mm}$ large-sized dye sensitized solar cells," Journal of Photochemistry and Photobiology A: Chemistry, vol. 164, no. 1-3, pp. 193-198, 2004. 


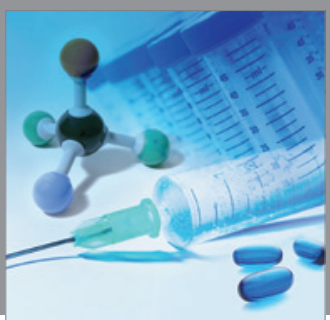

International Journal of

Medicinal Chemistry

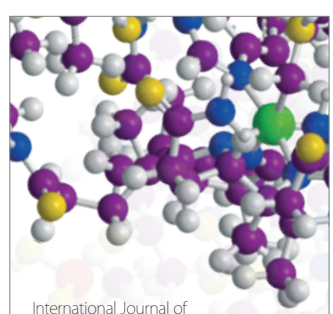

Carbohydrate Chemistry

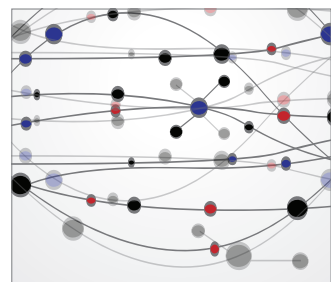

The Scientific World Journal
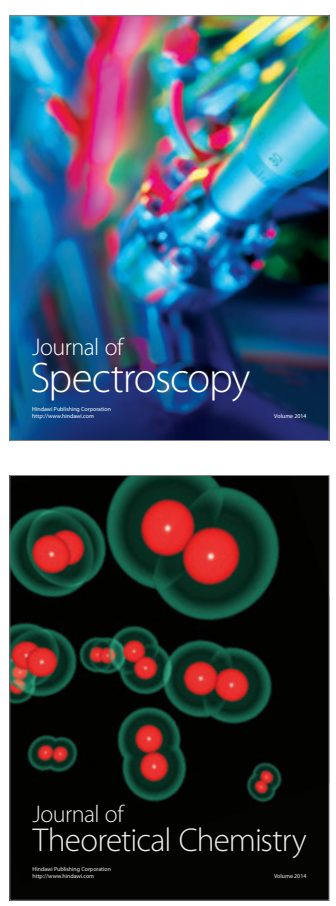
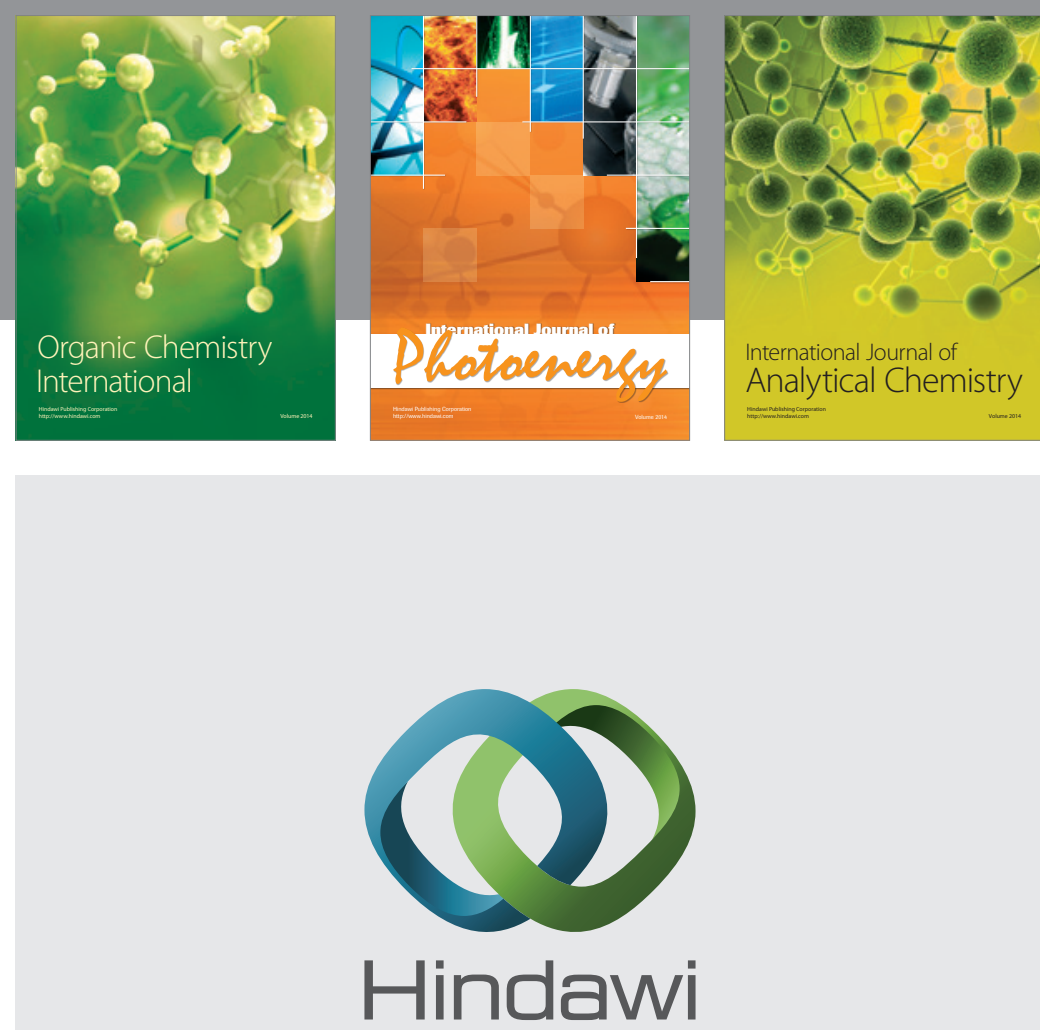

Submit your manuscripts at

http://www.hindawi.com
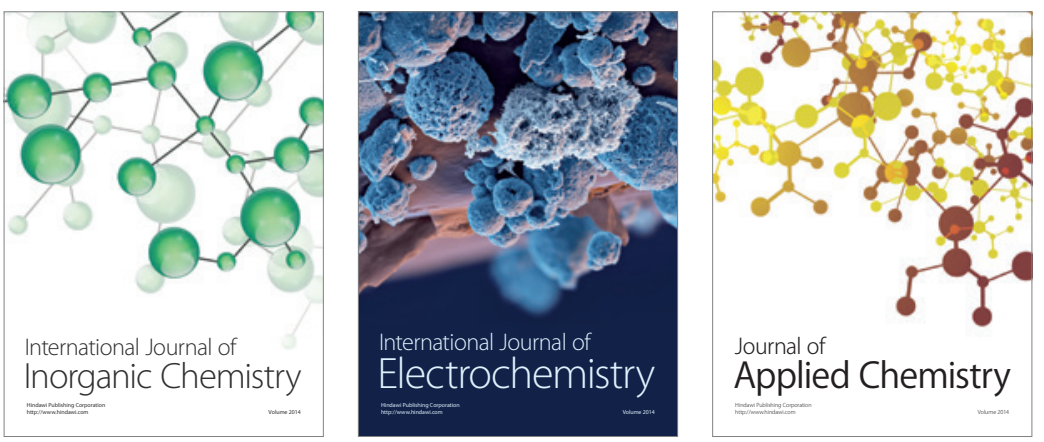

Journal of

Applied Chemistry
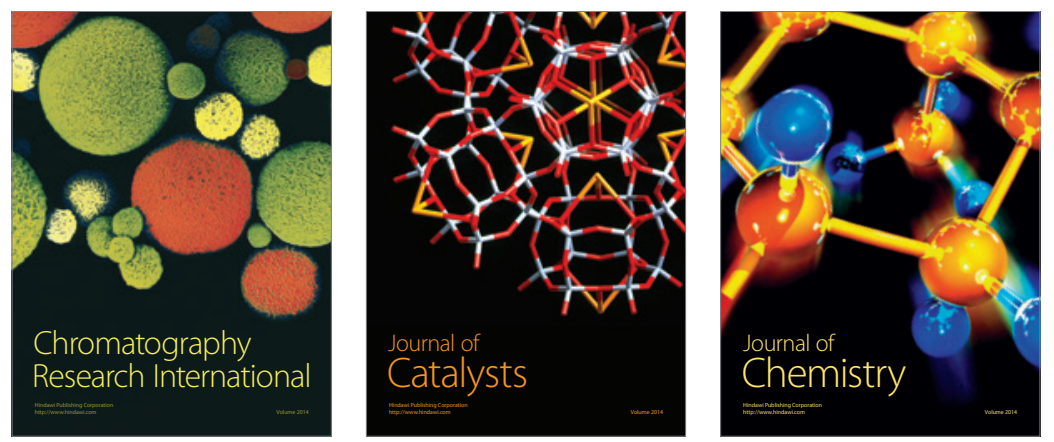
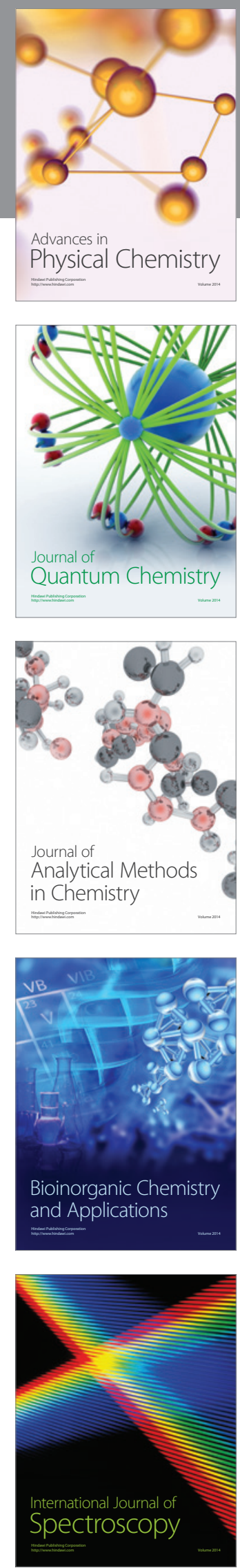